\title{
The utility of intravenous ketamine for the management of intraoperative penile erection: a retrospective single-center analysis of endourological surgeries over a 4-year
}

\author{
Aşkın Eroğlü*, Bahattin Tuncalı and Rahmi Gökhan Ekin ${ }^{3}$
}

\begin{abstract}
Background: To assess the prevalence of intraoperative penile erection in our endourology practice and the utility of intravenous ketamine in the management of the condition.

Methods: Of 402 endoscopic urological procedures performed in our clinic over a 4-year (2015-2019) period, a total of 9 cases with intraoperative penile erection impeding instrumentation during endourological surgery were included. Data on patient age, weight, height, American Society of Anesthesiologists (ASA) physical status classification system scores, type and duration of surgery, type and level of anesthesia, onset of erection, treatment characteristics and treatment outcome were recorded for each patient.

Results: The mean (SD) age was 68.3 years (range, 66.0-77.0 years). ASA physical status category I and II were noted in 55.6 and $44.4 \%$ of patients, respectively. All cases received spinal anesthesia $(n=9)$ at T8-10 dermatome levels, for TURP in 7 (77.8\%) cases and for TURBT in $2(22.2 \%)$ cases. The onset of penile erection was post-urethroscope in $7(77.8 \%)$ cases. The average total ketamine dose was $34.3 \mathrm{mg}$ (range, 18.0-75.0 mg). The average duration of the operation was $91.7 \mathrm{~min}$ (range, 40.0-140.0 min). Ketamine treatment resulted in resolved erection with delayed procedure in 7 (77.8\%) cases, while conversion to general anesthesia was required in 2 (22.5\%) cases.
\end{abstract}

Conclusions: In conclusion, the prevalence of intraoperative penile erection during spinal anesthesia for endourological surgery was $2.2 \%$ in our experience. These findings demonstrated that intravenous injection of ketamine is an effective and safe method for immediate resolution of intraoperative penile erection with a high success rate.

Keywords: Intraoperative penile erection · ketamine · endourology · treatment outcome

\section{Background}

Penile tumescence resulting in partial or total erection under anesthesia at the time of endoscopic urological surgery is a relatively infrequent but challenging condition with reported incidence of 0.1 to $2.4 \%$ [1-4]. While the etiology is unclear, it generally follows the local stimulation of the penis during skin preparation or instrumentation $[3,5]$. Intraoperative penile erection may

\footnotetext{
* Correspondence: askineroglu@gmail.com

'Department of Urology, Başkent University Research and Training Medical

Center, Izmir, Turkey

Full list of author information is available at the end of the article
}

lead to delay or cancellation of the surgery by impeding urological instrumentation or safely reaching the prostate or bladder together with the greater risk of complications such as bleeding, urethral trauma and stricture formation $[2,4,6]$.

To date, many pharmacological treatments to produce detumescence have been proposed, such as intracavernous injection of ephedrine, phenylephrine, metaraminol, noradrenaline and adrenaline $[4,7-10]$ or intravenous injection of ketamine [6, 11-13], dexmedetomidine [5], terbutaline [14] and glycopyrrolate [15].

(c) The Author(s). 2020 Open Access This article is distributed under the terms of the Creative Commons Attribution 4.0 International License (http://creativecommons.org/licenses/by/4.0/), which permits unrestricted use, distribution, and 
However, each of these has shown varying levels of efficacy and safety with no consensus a fully effective treatment protocol without side-effects [4-6].

The aim of this paper was to present the prevalence of intraoperative penile erection in our endourological surgery practice and the utility of intravenous ketamine in the management of the condition.

\section{Methods}

\section{Study population}

Of 402 endoscopic urological procedures performed in our clinic over a 4-year (2015-2019) period, a total of 9 cases with intraoperative penile erection development impeding instrumentation during endourological surgery were included in this retrospective study.

Written informed consent was obtained from each patient following a detailed explanation of the objectives and protocol of the study which was conducted in accordance with the ethical principles stated in the "Declaration of Helsinki" and was approved by the Institutional Ethics Committee.

\section{Assessments}

Data on patient age, weight, height, American Society of Anesthesiologists (ASA) physical status classification system scores, type and duration of surgery, type and level of anesthesia, onset of erection, treatment characteristics and treatment outcome were recorded for each patient.

\section{Management of intraoperative penile erection}

Intravenous ketamine treatment, titrated to a total dose of up to $75 \mathrm{mg}$ in accordance with Ramsay sedation score of 3 , was administered to resolve penile tumescence and rigid erection, which prevented performance of surgery. All patients also received midazolam $(0.02 \mathrm{mg} / \mathrm{kg})$ and fentanyl $(1 \mu \mathrm{g} / \mathrm{kg})$ to prevent ketamine-related complications. The surgical procedure was restarted in those with a successfully resolved rigid erection.

\section{Statistical analysis}

Statistical analysis was made using computer software (SPSS version 22.0, IBM, NY,USA). Descriptive statistics were stated as mean \pm standard deviation (SD), median, IQR (Inter Quartil Range) and percentage (\%), where appropriate.

\section{Results}

\section{Overall endourological surgery population}

The characteristics of the overall endourological surgery population $(n=402)$ are presented in Table 1 . The mean age was $69.1 \pm 10.2$ years. TURP (38.1\%) and TURBT (28.4\%) were the most common operations. Spinal anesthesia was applied to the majority of patients $(72.9 \%)$ and the average duration of surgery was 53.4 min. Intraoperative penile erection developed in $9(2.2 \%)$ patients (Table 1).

\section{Cases with intraoperative penile erection}

The individual and total characteristics of cases with intraoperative penile erection $(n=9)$ are presented in Table 2.

The mean (SD) age was 68.3 years (range, 66.0-77.0 years). ASA physical status category I 67 and II were noted in 55.6 and $44.4 \%$ of patients, respectively. All cases received spinal anesthesia $(n=9)$ at T8-10 dermatome levels, for TURP in 7 (77.8\%) cases and for TURBT in $2(22.2 \%)$ cases. The onset of penile erection was post-urethroscope in $7(77.8 \%)$ cases. The average total ketamine dose was $34.3 \mathrm{mg}$ (range, $18.0-75.0 \mathrm{mg}$ ) and the duration of the operation was mean $91.7 \mathrm{~min}$ (range, 40.0-140.0 min). Ketamine treatment resulted in resolved erection with delayed procedure in 7 (77.8\%) cases, while conversion to general anesthesia was required in 2 (22.5\%) cases (Table 2).

The cases with ketamine failure included a 74-year old patient undergoing TURP and a 77-year old patient undergoing TURBT and both were post-urethroscopic rigidities (Table 2).

\section{Discussion}

The findings of this study revealed that of 402 endourology operations performed in our clinic over a 4-year period (2015-2019), 9 (2.2\%) patients had a penile erection during endourological surgery with spinal anesthesia. Overall, 7 of $9(77.8 \%)$ cases were successfully treated with intravenous ketamine (total dose ranged from 18.0 to 75.0 $\mathrm{mg}$ ) administration, which resolved penile rigidity and the operation was completed within $91.7 \mathrm{~min}$ on average.

The overall prevalence of intraoperative penile erection under anesthesia has been reported to range from 0.1 to $2.4 \%$ [5], specifically at $0.34-3.5 \%$ for general anaesthesia, $0.11-0.3 \%$ for spinal anaesthesia and 1.72 $3.8 \%$ for epidural anaesthesia [3-5]. Hence, the prevalence of intraoperative penile erection in the current cohort of endourology patients seems to be consistent with previously reported rates for endourology procedures performed under spinal anesthesia.

Although the exact mechanism has not been clarified, penile erection under anesthesia is considered to be mediated by both psychogenic and refloxogenic stimulation $[4,14]$, while the latter is considered to be more common via the stimulatory effect of washing, touching and 67 instrumentation of the genital area on sacral root afferents [4]. Therefore, with the onset of penile erection post-urethroscope in $77.8 \%$ of the current study cases, these findings support the view that intraoperative penile erection generally follows local stimulation of the penis during skin preparation or instrumentation due to activation of sacral parasympathetic pathways eliciting an unopposed reflex response via an autonomic imbalance [3-5]. In addition, all of the intraoperative penile erection cases in this cohort had received spinal anesthesia 
Table 1 Characteristics of the overall endourological surgery population $(n=402)$

\begin{tabular}{|c|c|c|}
\hline \multicolumn{3}{|l|}{ Overall patient characteristics $(n=402)$} \\
\hline Age (years), mean (SD) & & $69.1(10.2)$ \\
\hline Median (IQR) & & $69(13)$ \\
\hline \multirow[t]{2}{*}{ Weight (kg) } & & $78.4(11.3)$ \\
\hline & & $78(15)$ \\
\hline \multirow[t]{2}{*}{ Height (cm) } & & $171.9(5.9)$ \\
\hline & & $172(8)$ \\
\hline \multirow[t]{3}{*}{ ASA physical status category, n (\%) } & । & $151(37.6)$ \\
\hline & $\|$ & $239(59.5)$ \\
\hline & III & $12(2.9)$ \\
\hline \multicolumn{3}{|l|}{ Comorbidities, n (\%) } \\
\hline Hypertension & & $174(43.3)$ \\
\hline Type 2 diabetes mellitus & & $81(20.1)$ \\
\hline Coronary artery disease & & $47(11.7)$ \\
\hline Arrhythmia & & $48(11.9)$ \\
\hline Chronic obstructive pulmonary disease & & $36(9.0)$ \\
\hline Chronic renal failure & & $5(1.2)$ \\
\hline Thyroid disease & & $8(2.0)$ \\
\hline Obstructive sleep apnea syndrome & & $2(0.5)$ \\
\hline \multicolumn{3}{|l|}{ Ankylosing spondylitis } \\
\hline & TURP & $153(38.1)$ \\
\hline \multirow[t]{7}{*}{ Type of surgery, n(\%) } & TURBT & $114(28.4)$ \\
\hline & Cystoscopy & $84(20.9)$ \\
\hline & Internal urethrotomy & $8(2.0)$ \\
\hline & Ureteroscopy & $2(0.5)$ \\
\hline & Cystolithotomy & $7(1.7)$ \\
\hline & Endoscopic ureter stone & $14(3.5)$ \\
\hline & TUR biopsy & $20(5)$ \\
\hline Duration of surgery (min), mean (SD) 53.4 (26.0) & & $53.4(26.0)$ \\
\hline \multirow[t]{2}{*}{ Type of anesthesia, n (\%) } & Spinal & $293(72.9)$ \\
\hline & General anesthesia & $109(27.1)$ \\
\hline \multirow[t]{2}{*}{ Intraoperative penile erection,n(\%) } & Yes & $9(2.2)$ \\
\hline & No & $393(97.8)$ \\
\hline
\end{tabular}

ASA American Society of Anesthesiologists, TURP Transurethral resection of the prostate, TURBT Transurethral resection of bladder tumor

with T8-T10 blockage, in accordance with the higher prevalence of erections with blocks reaching higher than T8 and rarely with those lower than T12 [16].

Notably, while the condition has been considered to occur predominantly in younger males [3-5], in the current cohort, the median age of patients with intraoperative penile erection was 69.0 years (range, 60.0-77.0 years), with the potential likelihood of treatment failure in older patients.

These findings demonstrated that the intravenous injection of ketamine was an effective and safe method for immediate relief of intraoperative penile erection with a high success rate. This supports the reported efficacy of ketamine, as a dissociative anesthetic, in the management of intraoperative penile erection in past studies [2, 6, 11-13].

Moreover, in 7 of 9 cases, ketamine administration resolved penile rigidity enabling completion of the operation within an average of $91.7 \mathrm{~min}$ with no side-effects. This seems notable given the consideration of prolonged time to achieve flaccidity (range, $90 \mathrm{~min}^{-2} \mathrm{~h}$ ) being the major disadvantage of intravenous ketamine treatment, together with the potential risk of hallucinations and unpleasant dreams in patients under concomitant spinal anesthesia $[4,11,17]$.

Certain limitations to this study should be considered. First, due to the retrospective single 12345 center 
Table 2 Cases with intraoperative penile erection $(n=9)$

\begin{tabular}{|c|c|c|c|c|c|c|c|}
\hline Case & ASA & $\begin{array}{l}\text { Typeof } \\
\text { surgery }\end{array}$ & $\begin{array}{l}\text { Duration of } \\
\text { surgery }\end{array}$ & $\begin{array}{l}\text { Anesthesia/ } \\
\text { Level }\end{array}$ & $\begin{array}{l}\text { Onset of } \\
\text { erection }\end{array}$ & Treatment & Outcome \\
\hline 1 & 1 & TURP & 55 & Spinal/T10 & $\begin{array}{l}\text { Post- } \\
\text { urethroscope }\end{array}$ & $\begin{array}{l}\text { Ketamine } 75 \\
\mathrm{mg}\end{array}$ & $\begin{array}{l}\text { Conversion to } \\
\text { GA }\end{array}$ \\
\hline 2 & 1 & TURP & 90 & Spinal/T8 & $\begin{array}{l}\text { Post- } \\
\text { urethroscope }\end{array}$ & $\begin{array}{l}\text { Ketamine } 25 \\
\mathrm{mg}\end{array}$ & $\begin{array}{l}\text { Delayed } \\
\text { procedure }\end{array}$ \\
\hline 3 & 2 & TURBT & 130 & Spinal/T8 & $\begin{array}{l}\text { Post- } \\
\text { urethroscope }\end{array}$ & $\begin{array}{l}\text { Ketamine } 50 \\
\mathrm{mg}\end{array}$ & $\begin{array}{l}\text { Conversion to } \\
\text { GA }\end{array}$ \\
\hline 4 & 1 & TURP & 140 & Spinal/T10 & $\begin{array}{l}\text { Pre- } \\
\text { urethroscope }\end{array}$ & $\begin{array}{l}\text { Ketamine } 25 \\
\mathrm{mg}\end{array}$ & $\begin{array}{l}\text { Delayed } \\
\text { procedure }\end{array}$ \\
\hline 5 & 2 & TURBT & 40 & Spinal/T10 & $\begin{array}{l}\text { Post- } \\
\text { urethroscope }\end{array}$ & $\begin{array}{l}\text { Ketamine } 20 \\
\mathrm{mg}\end{array}$ & $\begin{array}{l}\text { Delayed } \\
\text { procedure }\end{array}$ \\
\hline 6 & 2 & TURP & 90 & Spinal/T8 & $\begin{array}{l}\text { Post- } \\
\text { urethroscope }\end{array}$ & $\begin{array}{l}\text { Ketamine } 21 \\
\mathrm{mg}\end{array}$ & $\begin{array}{l}\text { Delayed } \\
\text { procedure }\end{array}$ \\
\hline 7 & 1 & TURP & 95 & Spinal/T8 & $\begin{array}{l}\text { Post- } \\
\text { urethroscope }\end{array}$ & $\begin{array}{l}\text { Ketamine } 18 \\
\mathrm{mg}\end{array}$ & $\begin{array}{l}\text { Delayed } \\
\text { procedure }\end{array}$ \\
\hline 8 & 1 & TURP & 90 & Spinal//T10 & $\begin{array}{l}\text { Pre- } \\
\text { urethroscope }\end{array}$ & $\begin{array}{l}\text { Ketamine } 25 \\
\text { mg }\end{array}$ & $\begin{array}{l}\text { Delayed } \\
\text { procedure }\end{array}$ \\
\hline 9 & 2 & TURP & 95 & Spinal/T8 & $\begin{array}{l}\text { Post- } \\
\text { urethroscope }\end{array}$ & $\begin{array}{l}\text { Ketamine } 50 \\
\mathrm{mg}\end{array}$ & $\begin{array}{l}\text { Delayed } \\
\text { procedure }\end{array}$ \\
\hline
\end{tabular}

Total $(n=9)$

Age (years)

Mean (SD)

$68.3(6.6)$

Weight (kg), mean Median (IQR)

$69.0(8)$

Median (IQR)

$80.7(7.8)$

Height (cm), mean

(SD)

$82(6)$

Median (IQR)

$172(5)$

$174.6(7.7)$

ASA physical status

category, n (\%)

।

Type of operation, $\mathrm{n} \quad$ ॥

(\%)

II

5 (55.6)

$4(44.4)$

$7(77.8)$

Type of anesthesia, $\mathrm{n}$

TURP

$2(22.2)$

9 (100.0)

Level of anesthesia, $\mathrm{n}$ General

$0(0.0)$

(\%)

$\mathrm{T} 10$

$4(44.4)$

T8 Post

5 (55.6)

Onset of erection

urethroscope Pre

7 (77.8)

urethroscope

2 (22.2)

Ketamine total dose

Mean (SD)

34.3 (19.5)

(mg)

Median (min-max)

$25.0(18.0-75.0)$

Duration of operation Mean (SD)

(min)

Median (min-max)

91.7 (31.3)

$90.0(40.0-$

140.0)

Outcome, n (\%)

Resolved-delayed

7 (77.8)

procedure

2 (22.2) 
design of the study, establishing the temporality between cause and effect seems difficult. Second, generalizing these findings to the whole endourology population is not 67 possible due to the relatively low sample size. Nevertheless, despite these certain limitations, given the paucity of solid information available in accordance with the rarity of the condition and the challenges regarding conduction of very large-scale studies to determine the benefits of any therapeutic intervention, these findings represent a valuable contribution to the literature.

\section{Conclusion}

In conclusion, the prevalence of intraoperative penile erection during spinal anesthesia for endourological surgery was $2.2 \%$ in our experience. These findings demonstrated that intravenous injection of ketamine is an effective and safe method for immediate resolution of intraoperative penile erection with a high success rate.

\section{Abbreviations}

ASA: American society of anesthesiologists; TURBT: Transurethral resection of bladder tumor; TURP: Transurethral resection of prostate

\section{Acknowledgements}

Not applicable.

\section{Authors' contributions}

$A E$ and $B T$ conceived and designed the study; $A E, B T$ and RGE as corresponding researchers collected clinical information; $A E$ and RGE organized and input the data; BT checked and verified data input by AE and RGE; AE and RGE performed statistical analyses; AE drafted the manuscript; BT revised the manuscript. All authors have read and approved the final version.

\section{Funding}

No funding was obtained for this study.

\section{Availability of data and materials}

The datasets used and/or analysed during the current study are available from the 12345 corresponding author on reasonable request.

\section{Ethics approval and consent to participate}

This research is retrospective and involving the collection of existing data and records. The ethical committee of Baskent University approved all procedures of the study and written informed consent was obtained from all cases.

\section{Consent for publication}

Consent was obtained.

\section{Competing interests}

The authors declare that they have no competing interests.

\section{Author details}

'Department of Urology, Başkent University Research and Training Medical Center, Izmir, Turkey. ${ }^{2}$ Department of Anesthesia and Reanimation, Başkent University Research and Training Medical Center, Izmir, Turkey. ${ }^{3}$ Department of Urology, Urla State Hospital, Izmir, Turkey.

Received: 17 April 2019 Accepted: 3 January 2020

Published online: 28 January 2020

\section{References}

1. Walther PJ, Meyer AF, Woodworth BE. Intraoperative management ofpenile 1112 erection with intracorporeal phenylephrine during endoscopic surgery. J Urol. 1987;137:738-9.
2. Baltogiannis DM, Charalabopoulos AK, Giannakopoulos XK, Giannakis DJ, Sofikitis NV, Charalabopoulos KA. Penile erection during transurethral surgery. J Androl. 2006;27:376-80.

3. Staerman F, Nouri M, Coeurdacier P, Cipolla B, Guille F, Lobel B. Treatment of the intraoperative penile erection with intracavernous phenylephrine. J Urol. 1995;153:1478-81.

4. Gray M, Vasdev N, Gowrie-Mohan S, McNicholas T (2017) The Managementof unplanned erection during endoscopic urological surgery. Curr Urol10:113-117.

5. Guler G, Sofikerim M, Ugur F, Aksu R, Boyaci A. Intravenous dexmedetomidine for treatment of intraoperative penile erection. Int UrolNephrol. 2012;44:353-7.

6. Tuncali B, Tuzel E. Management of Penile Erection Using IntravenousKetamin which is impeding urologic instrumentation under spinal anesthesia: CaseReport. Turkiye Klinikleri J Urology. 2014:5:62-5.

7. Siegel JF, Reda E. Intracorporeal phenylephrine reduces thioridazine (Mellaril) induced priapism in a child. J Urol. 1997;157:648.

8. de Meyer JM, De Sy WA. Intracavernous injection of noradrenaline tointerrupt erections during surgical interventions. Eur Urol. 1986;12:169-70.

9. Zappala SM, Howard PJ, Hopkins TB, Blute RD. Management of intraoperative penile erections with diluted epinephrine solution. Urology. 1992:40:76-7.

10. Tsai SK, Hong CY. Intracavernosal metaraminol for treatment ofintraoperative 67 penile erection. Postgrad Med. 1990:J66:831-3.

11. Benzon HT, Leventhal JB, Ovassapian A. Ketamine treatment of penileerection in the operating room. Anesth Analg. 1983:62:457-8.

12. van Arsdalen KN, Chen JW, Smith MJ. Penile erectioncomplicating transurethral surgery. J Urol. 1983;129:374-86.

13. Gale AS. Ketamine prevention of penile turgescence. JAMA. 1972;219:1629.

14. Shantha TR. Intraoperative management of penile erection by usingterbutaline. Anesthesiol. 1989;70:707-9.

15. Valley MA, Sang CN. Use of glycopyrrolate to treat intraoperativepenile erection: case report and review of the literature. Reg Anesth. 1994:19:423-8.

16. Pertek JP, Coissard A, Artis M. Dorsal nerve block forintraoperative management of penile erection. Reg Anesth. 1996;21:491-2.

17. Ravindran RS, Dryden GE, Somerville GM. Treatment of priapismwith ketamine and physostigmine. Anesth Analg. 1982;61:705-7.

\section{Publisher's Note}

Springer Nature remains neutral with regard to jurisdictional claims in published maps and institutional affiliations.
Ready to submit your research? Choose BMC and benefit from:
- fast, convenient online submission
- thorough peer review by experienced researchers in your field
- rapid publication on acceptance
- support for research data, including large and complex data types
- gold Open Access which fosters wider collaboration and increased citations
- maximum visibility for your research: over $100 \mathrm{M}$ website views per year
At $\mathrm{BMC}$, research is always in progress.
Learn more biomedcentral.com/submission 